\title{
Modelling the medieval economy: money, prices and income in England, 1263-1520
}

Book or Report Section

Accepted Version

Casson, C. and Casson, M. (2015) Modelling the medieval economy: money, prices and income in England, 1263-1520. In: Allen, M. and Coffman, D.'M. (eds.) Money Prices and Wages: Essays in honour of Professor Nicholas Mayhew. Studies in the History of Finance. Palgrave Macmillan, Basingstoke, pp. 51-73. ISBN 9781137394019 Available at https://centaur.reading.ac.uk/49603/

It is advisable to refer to the publisher's version if you intend to cite from the work. See Guidance on citing.

Publisher: Palgrave Macmillan

All outputs in CentAUR are protected by Intellectual Property Rights law, including copyright law. Copyright and IPR is retained by the creators or other copyright holders. Terms and conditions for use of this material are defined in the End User Agreement.

\section{www.reading.ac.uk/centaur}

\section{CentAUR}


Central Archive at the University of Reading

Reading's research outputs online 
Modelling the medieval economy: Money, prices and income in England, 1263-1520

Mark Casson (University of Reading) and Catherine Casson (University of Birmingham)

Word count (inclusive of all tables etc.): 8631

\section{Introduction}

This chapter presents a simple econometric model of the medieval English economy, focusing on the relationship between money, prices and incomes. The model is estimated using annual data for the period 1263-1520 obtained from various sources. The start date is determined by the availability of continuous runs of annual data, while the finishing date immediately precedes the take-off of Tudor price inflation. Accounts from the ecclesiastical and monastic estates have survived in great numbers for this period, thereby ensuring that crop yields can be estimated from a regionally representative set of estates.

The relationship between money and prices in the medieval period has been hotly debated. This chapter addresses this debate within a wider context. The evidence base includes the price level, the stock of gold coin, the stock of silver coin, real income (gross domestic product (GDP) per head), population, money wage rates and crop yields. The study makes full use of Mayhew's (2013b) recent series for the English money stock 1220-1750. Following normal practice in economic research, prices, wages, money and incomes are all expressed in logarithmic terms.

Section 2 discusses methodology. Section 3 describes the data sources. Section 4 presents a simultaneous equation model (SEM) in which variations in annual prices, incomes and wages are explained by interactions between each other, and by the impacts of money, population, crop yields and time trends. Sections 5 presents the results of estimating the SEM, and section 6 discusses the implications for future research.

\section{Methodology}

\section{The advantages of using annual data}

Statistical evidence on the relation of money to prices is often analysed using ten-year averages of price inflation and growth of the money supply (Mayhew, 2013a). A ten-year average smooths out short-run fluctuations that can mask long-term trends. The disadvantage, however, is that averaging suppresses potentially useful information. Short run fluctuations may not be purely random. Patterns of short-run covariation are suppressed when averages are taken, and valuable insights can be lost. When annual data is available, it is best to work with it throughout.

Theories of money and inflation can be debated by comparing graphs of prices and money supply. Graphs are certainly suggestive, but their interpretation is subjective unless supported by statistical calculation, e.g. visualisation can be biased by seeking out expected patterns, and failing to appreciate that they can be easily generated by random fluctuations.

\section{Limitations of correlation analysis}


Correlation coefficients are often used as a measure of association between different series. Correlations can be applied either to cross-sections (e.g. prices in different towns at the same time) or to time series (e.g. correlations between the prices and money supply over time). Correlations estimated for cross-sections are often relatively low, but correlations for time series are often high. When several different time series are examined, the patterns of correlation between individual series can be strongly influenced by their trends. If a pair of variables both trend in the same direction they may appear positively correlated and if they trend in opposite directions they may appear negatively correlated, but once the trends are removed a completely different pattern may appear. This applies to the present study, where different variable trend in different ways (see Table 1).

It is well known that correlation does not imply causation (Kenny, 1979). A positive correlation between money and prices, for example, could be due to money influencing price (the usual view), or to price influencing money, or to both prices and money being influenced by some third factor (e.g. population or a common trend). The effect of a third factor can be neutralised by calculating a partial correlation coefficient, but this still leaves the direction of direct causation unresolved.

A cause usually precedes its effect. If money causes prices then prices this year may be correlated with money supply the previous year, whereas if prices cause money then money supply this year may be correlated with prices the previous year. Thus if current price is correlated with previous money stock it could be inferred that money cause prices, whereas if current price is correlated with previous price is also correlated it could be inferred that prices cause money. An exercise of this kind is the basis of the Granger causality test (Wooldridge, 2014). This chapter follows a different approach, however.

\section{Causation in the Quantity Theory}

In economic models the direction of causation is usually suggested by theory. Economic models based on the Quantity Theory of Money (QT) assume that causation runs from money to price rather than the other way round (Fisher, 1911, Friedman, 1956). Price measures the value of goods in terms of money and, conversely, the inverse of price measures the value of money in terms of goods. Prices are determined by markets and the market value of money depends upon the available supply of money. The supply of money does not depend upon prices because it is largely determined by the stock of money inherited from previous periods.

The QT makes other assumptions that are not so reasonable, however. It assumes that causation runs from output to price rather than from price to output. When the labour market is perfectly competitive, and wage rates are perfectly flexible, the economy is always at full employment. Full-employment output is determined by long-run factors such as technology, population and land supply, and not by short-run fluctuations in price. In practice, however, output may respond to price (Nerlove, 1958). This could occur, for example, if wages are sticky rather than flexible. For a given wage, the higher the price, the greater the profitability of production, and hence the larger the output that will be produced. In this case price 
depends upon output, and output depends on price, and so causation runs in both directions at once.

\section{Simultaneous equation models and the use of lags to identify causation}

Interactions of this kind can be addressed using an SEM. SEMs distinguish between endogenous variables, that are causally determined, and exogenous variables that causally determine them, but are not themselves caused by any factor included in the model. Instead of taking price as the main endogenous variable, the model treats output and wages as endogenous too. If price influenced output at the same time that output influenced price then it would be impossible to disentangle the two effects using evidence from a single correlation coefficient. The same problem would arise if wages influenced prices at the same time that prices influenced wages.

Interacting effects can be separately identified by postulating lags (Fisher, 1966). If product markets are efficient and production is instantaneous then the supply of output will influence price immediately, but if there is a production lag then price may influence output only the following year. The correlation between current price and current output can therefore be analysed in terms of price adjustment, whilst the correlation between past price and current output can be interpreted as supply response to price in the presence of a production lag. A production lag also implies that the impact of wages on price will be delayed. A correlation between current price and the previous wage can be interpreted in terms of passing on to customers a change in the cost of production, whilst a correlation between current wage and past price can be interpreted in terms of retrospective cost-of-living wage adjustment.

With three endogenous variables, and one equation explaining each, the SEM contains three equations altogether. Each equation contains an unobserved random factor (or 'shock') that accounts for the deviation between the actual measurements on the endogenous variable and their predicted values. If these random factors are uncorrelated then each equation can be estimated independently of the others. Under suitable conditions a multiple linear regression (MLR) can be estimated by ordinary least squares (OLS). An MLR makes it possible to control for the influence of other variables when estimating the impact of given exogenous variable.

\section{Autocorrelation and unit root processes}

The idea of correlating the current value of one variable with the lagged value of another leads naturally to the concept of autocorrelation, in which the current value of a variable is correlated with its own lagged values. In common with many economic times series, some of the variables in this study exhibit high autocorrelations. They are often correlated more strongly with their own past values than with the past values of other variables; it appears that, to some extent, they cause themselves.

Autocorrelation implies that history matters, in the sense that the current value of a variable is linked to its previous values. This raises an important philosophical question. Does the influence of the past become more or less important with the passage of time? For example, 
population fell sharply at the time of the Black Death, but is it still lower today as a result? Common sense suggests that the influence of past events decays, but statistical evidence sometimes seems to point in the opposite direction.

Economists used to assume that an economy was subjected to transitory shocks rather than permanent shocks, so that the economy reverted towards a normal state, e.g. a long-run equilibrium, after every change. Many economists now believe in random walks and 'unit root processes' that have no tendency to revert to normal after a shock; once a shock has occurred the effect persists for ever (Wooldridge, 2014). Persistence itself is not an issue provided that impacts decay over time. But if persistence is indefinite (i.e. there is a 'unit root') then effects do not decay, and variance increases without limit, undermining the standard statistical tests of significance used in econometric research. The Augmented Dickey-Fuller (ADF) test is used to test for the presence of unit roots. The test is rather weak, however. It cannot easily distinguish between indefinite persistence and slow decay, and is quite likely to suggest a problem where none in fact exists. The test must therefore be applied with caution.

The test statistic depends on whether linear trends are extracted from the data first. It also depends on whether the data is expressed in terms of levels or changes. Table 3 presents three ADF statistics for each variable. The first refers to the level before a trend has been extracted, the second to the level after the trend has been extracted, and the third to the change in level after the trend has been extracted. In this context the middle column is the most appropriate. The results indicate that unit roots can be rejected at 1 per cent significance for prices and crop yields, and at 10 per cent significance for the gold stock.

For other variables unit roots cannot be rejected. The potential for unit roots is strongest in the case of population and the silver stock. Common sense suggests, however, that persistence in the population figures reflects the lifetime of a typical individual, whilst persistence in the silver stock reflects the frequency of recoinages. Combining the ADF results with the autocorrelations reported in Table 2 suggests that population and silver stock have persistence factors of about 90 per cent. Although this is close to a unit root, it is fundamentally different in a statistical sense, because without a unit root the variance of the series is stable over time.

\section{Sources}

\section{Prices and wages}

Data on agricultural prices were originally compiled by Thorold Rogers (1866-1902), developed by Beveridge (1939) and refined by Phelps Brown and Hopkins (1962), who also created an index of builders' wages. Farmer (1991) and Clark (2004) extended the scope of the commodity price series, and Allen $(2001,2013)$ constructed a wage index and cost of living index designed to facilitate comparisons of international living standards. Allen's figures are the basis for this study; they are nominal sterling values expressed in logarithms. 
The evidence suggests that a long period of price stability from the time of the Norman Conquest (and possibly earlier) was succeeded by a rise in prices 1170-1300 (Mayhew (2013a). There were several spikes in prices 1300-48, although from 1320 the underlying trend was downward. Prices rose 1348-70, and then began a further decline 1370-1500, after which a upward trend resumed. Prices spiked in 1440 and slumped 1440-60, which is generally regarded as a period of trade depression (Hatcher and Bailey, 2001).

\section{Money stock}

Until recently historical information on money stocks was incomplete. The stock of coinage in any year must be inferred from records of the outputs of mints and analysis of the evidence from coin hoards. Mint outputs can be cumulated over time to generate a stock figure, but the initial value of the stock can be difficult to assess. Coin stocks depreciate through wear, and the rate of depreciation can be inferred from hoards, and from the state of coin taken in at recoinages. Recoinages also provide benchmark figures for the subsequent money stock.

Sterling coinage was exclusively silver until 1344. Thereafter the stock of gold coinage grew rapidly until 1370, and then declined, 1370-1411. In the meantime the stock of silver coinage increased 1250-1310, when it began a rapid decline, 1310-1412, punctuated only by a brief recovery 1350-56. By 1412 silver was less than 20 per cent of the gold stock (in nominal sterling value). The gold stock peaked in 1424 , declined to 1463 , and then slowly increased 1463-1520. The silver stock also recovered slowly, 1412-1520. Using estimates of mint output from Challis (1992) and Allen (2012), Mayhew has constructed annual series for both silver and gold coin, 1220-750 (Mayhew, 2013b), which are used in this chapter.

The QT is essentially a theory of the circulation of money, but it is difficult to know how much money was actually circulated and how much was hoarded. It is difficult to assess the export of coin, although imports were almost certainly small; foreign coin had to be exchanged for sterling coinage, and the crown enforced this effectively. International transactions could, however, be off-shored, e.g. by transacting in a foreign currency in a staple port rather than in sterling in London.

Coin is not the only component of money stock in a modern economy; cheque deposits, credit card balances, and short-term bills are important too. Bills circulated in medieval England, but annual figures for the stock of bills are difficult to obtain. Informal local credit was available too. In principle, credit could expand at times of monetary contraction to neutralise the effects of changes in the stock of coin, but Mayhew (2013a) argues that in practice the opposite occurred: credit expanded and contracted in line with the money supply, and thereby amplified rather than dampened the impact of money on the economy. Likewise he argues that payment in gold and silver jewellery and plate was not an adequate substitute for the use of coin.

\section{Income and population}

Output comprises a mixture of different commodities, and is usually measured in terms of gross domestic product (GDP). In this study the output indicator is GDP per head (or 
'income' for short). This is derived from estimates of GDP and population compiled by Broadberry, Campbell, Klein, Overton and van Leeuwen (2011). GDP is calculated at constant prices using modern procedures for national income accounting, and this allows the series to be linked to existing post-1750 series.

Crop yields are derived from a database compiled by Campbell (2007) which draws upon various regional studies of manorial accounts (including some of his own). The data comprises an index of yields for three key crops: barley, wheat and oats, 1270-1470, supplied by the author. Crop yields are the most volatile of the time series (high variance and low autocorrelation) and exhibit a downward trend. Crop yields are also used in the computation of GDP.

Medieval population figures are well known to be problematic, as the sources permit estimates to be made only for certain dates. As a result, annual population statistics rely heavily on interpolation. It is therefore unreasonable to include both current and lagged values of population in regression analysis because the estimated lag structure may simply reflect the method of interpolation used. It is also uncertain exactly what proportion of the population was enumerated at each date. As a result, there is a wide margin between 'high' and 'low' estimates of medieval population, even when there is broad agreement over whether population was rising or falling at the time.

\section{A comment on interest rates}

A complete macroeconomic model of the medieval economy would use data on interest rates. According to Keynesian monetary theory, an increase in interest rates increases the opportunity cost of holding money balances and thereby stimulates the velocity of circulation; as a result, the impact of money on prices will be reduced. Long-term interest rates can, in principle, be inferred from a comparison of the capital values and the annual rents of properties, whilst short-term interest rates can be inferred from the values of discounted bills. Unfortunately, however, insufficient evidence has so far been collected to generate a reliable annual time series.

\section{Structure of the model}

The SEM is derived algebraically in the appendix and is summarised schematically in Figure 1. In the figure exogenous variables appear on the left, and endogenous variables on the right. For simplicity, silver and gold stocks are combined in the top left-hand box, representing money supply, while population and time (two strongly trended variables) are combined in another box lower down. The three middle boxes on the left-hand side represent lagged values of the endogenous variables. These are not strictly exogenous variables, but rather 'pre-determined' variables, but they may be treated as exogenous so far as any given year is concerned (Wooldridge, 2014). A full description of the model would also portray the unobserved random shocks that impinge on each of the endogenous variables.

The impacts of exogenous variables on endogenous variables are presented by arrows. Theory suggests that money supply impacts mainly on prices, and that it affects wages and 
income only through knock-on effects. For this reason the arrow from money supply impinges only on price. All the other exogenous variables impact on each of the endogenous variables.

There is one endogenous variable that impacts on another: namely current income impacts on price. Whilst lagged values of endogenous variables impact on other variables, income is the only endogenous variable whose current value impacts on the current value of another endogenous variable. Because the impact goes in only one direction, it is fully identified according to the criteria described in section 2 .

The period of this study was regularly punctuated by 'extreme events' such as wars, famines and plagues (affecting both people and animals). From a statistical point of view, these events are treated as random but perfectly normal, and are not addressed by omitting outlying observations or introducing dummy variables. If dummy variables are introduced for the Black Death, or the Peasants' Revolt, for example, then some of the results, especially those relating to population and income, are changed. The impacts of these events seem to be quite well explained by the model as it stands, however, and meddling with the model does not substantially improve the overall fit.

There are 17 separate impacts identified numerically in the figure. Four of these impacts have two variants; the impact of money on price is different for silver and gold, and the impacts of population and time trend must be differentiated too. Thus there are 21 impacts altogether. These impacts are listed in the first column of Table 4 . In 15 cases theory predicts the sign of the impact, as indicated in the second column. The remaining columns summarise the results presented below.

\section{Results}

Each equation in the SEM is estimated separately by OLS MLR. Table 5 shows some preliminary results for the price regression. Column 1 shows that simply extracting a time trend removes nearly 60 per cent of the variance in price $\left(R^{2}=0.598\right)$. The trend coefficient is large because time is measured in centuries rather than years in order to give plenty of significant figures in the coefficient. Because price is measured in logarithms, a negative linear trend implies exponential decay. This downward trend is evident in the graph of actual prices shown in Figure 2.

Regression on a linear trend only makes sense if the normal level of price lies on the trend line and deviation from trend is purely transitory. In practice, the price series wanders about, remaining above trend for some time, and then below trend for some time, and so on. This is due to autocorrelation, which generates persistence in the price. Column 2 introduces the previous price to address this issue. More than half of the unexplained variance from the previous equation is now accounted for $\left(R^{2}=0.842\right)$. Last year's price carries a weight of over three quarters (0.767) in determining the current price. Both the time trend and the lagged price are significant at 1 per cent. Although the linear trend remains significant, its coefficient is reduced to a quarter of its previous size. 
Additional price lags are introduced in column 3, but their contribution is small $\left(R^{2}\right.$ increases by only 0.010 ). Persistence is measured by the sum of the three price coefficients, and at 0.766 is virtually unchanged from its previous value.

Silver and gold stocks are introduced in column 4. A dummy variable is introduced to account for 'hidden' gold that may been in circulation prior to the minting of gold in 1344 (Mayhew, 2013b). However, none of these variables is significant in this exploratory analysis.

Income and population are introduced in column 5. The QT predicts that income will have a negative impact on price, and specifically that a one per cent increase in income will generate a one per cent fall in prices. The highly significant coefficient of -0.928 strongly supports this view.

Lagged wages are introduced in column 6 . The wage rate is strongly significant and carries the expected positive sign. The coefficient of 0.909 suggests that over 90 recent of any increase in wages is reflected in price increases the following year.

Reviewing the table indicates that the signs and significance of the coefficients on lagged prices, money stocks and income do not change dramatically as additional variables are included. Substantial changes, occur, however, once crop yields are introduced in column 7. There are two reasons why such changes may occur. First, crop yield data is only available until 1470, so that the final 50 years of the analysis disappear due to missing observations. Secondly, crop yields have been widely recognised as a significant influence on agricultural prices, and so that there omission for the previous regressions was an important weakness; other variables may have appeared significant simply because they were correlated with this important omitted variable.

The introduction of crop yields renders income insignificant and makes silver a significant influence on price. The insignificance of income may be explained by the fact that crop yields are used in the calculation of GDP, as noted above. Grains carry a heavy weight in Allen's price index, and so it is possible that crop yields and GDP play similar roles as determinants of price. (Although crop yields and income are not highly correlated, this is only because they have opposing trends, as shown in Table 1). The significance of the silver stock is plausible in terms of the QT; furthermore, Mayhew (2013a) has argued that silver rather than gold that was the main determinant of price during this period. The tests for serial correlation and heteroskedasticity in the final column indicate no significant problems, and thereby reinforce the view that no unit root is involved in price formation.

A similar exploratory exercise was carried out for the income and wage regressions, but the results are not reported here, as no additional issues were raised.

The full SEM was estimated without crop yield data for the full period 1263-1520, and with crop yield data for the period 1263-1470. The results including crop yields are reported in Table 6. The SEM sheds light on all the potential impacts identified in Table 4. For each 
impact, the third column compares the actual result with the predicted result, while the final column comments on the outcome.

The results excluding crop yields are not tabulated, but are summarised graphically in Figure 2-4. These graphs show that the SEM generates a remarkably good fit for all three regressions.

The results support the QT, but only in a qualified way. They confirm Mayhew's contention that it is silver rather than gold that influences price. Indeed, the gold stock has no significant influence on price. (Not that the same conclusion could be drawn from a superficial comparison of the zero-order correlations in Table 1.) A possible explanation is that silver circulated widely as small change, but gold tended to be hoarded, or only intermittently exchanged in large transactions.

The results do not support the view that increases in income reduce prices as the QT suggests. The explanation may be, however, that crop yields are a better proxy for output than is income. Considered as an output measure, crop yields have the negative impact on price that is predicted by the QT. It is a long-established view that prices rise in times of famine (Campbell and O'Grada, 2011; Hoskins, 1964). This is often ascribed to a rise in the price of agricultural products relative to manufactures, but it could also be ascribed, in terms of the QT, to the effect of a fall in agricultural output relative to a fixed stock of money. In a predominantly agricultural economy this is, indeed, the more plausible scenario. In this context, the QT could be interpreted as a theory of the circulation of the coins used for small transactions in the dominant agricultural sector of the economy.

In the simple QT output is fixed at the full-employment level. The evidence suggests, however, that output responds to price. A rise in price stimulates output, supporting the view that producers respond to changing expectations of market conditions. This view is reinforced by the fact that wages are relatively sticky in the short run. The persistence of wages is much greater than the persistence of prices, so that an increase in price will increase profits because of inertia in the wage. This suggests that the Keynesian critique of the QT has substance. The impact of a monetary change will be spread across prices and income and not focused on prices alone. Thus money is not a such powerful determinant of price as the simple QT suggests.

Contrary to Mayhew's view, population has a positive impact on prices. This phenomenon has been noted before, and interpreted in terms of Keynesian theory: a high population stimulates demand, and boosts prices (Postan, 1973). But as Mayhew has pointed out, higher population can also boost supply (1995). There is an alternative explanation of the impact of population on price, however, which is consistent with the SEM results. With a fixed stock of land in a predominantly agricultural economy, there may be diminishing marginal returns to labour and hence to population. With sticky money wages and diminishing returns to more intensive cultivation, high population will reduce the productivity of labour, and with fixed money wages this may translate into higher prices. This mechanism is consistent with the negative impact of population on GDP per head in the model. 


\section{Implications for future research}

To the best of our knowledge, SEMs have not been used before to analyse the medieval economy. Data on the medieval economy can always be criticised for being subject to error and somewhat incomplete. But whatever the quality of the data, it does not help to compound the problem by using inappropriate statistical methods. Historical applications of correlation analysis have sometimes been criticised, and rightly so, for using inappropriate methods. The appropriate response, however, is not to avoid statistical methods, but use more sophisticated ones instead. The SEM has many attractions for historians because it is well adapted to analysing the incremental evolution of the economy as a complex interdependent system. Less sophisticated methods often treat the economy as if it were a rigid mechanistic system instead.

This chapter has considered only one of the many possible applications of SEMs to medieval economic modelling. SEMs can be applied to individual price series as well as to price indexes (Casson, Hashimzade and Casson, 2013). They can be used to investigate other aspects of the monetary economy, and to explain volatility in income. It is also possible to analyse the residuals for SEMs to identify hidden factors that underlie long-term trends, key structural breaks, or episodic disasters. It is hoped that this chapter will encourage others to exploit the analytical potential of the SEM in related fields of research.

\section{References}

Allen, Martin (2012) Mints and Money in Medieval England, Cambridge: Cambridge University Press

Allen, Robert C. (2001) The great divergence in European wages and prices from the Middle Ages to the First Wold war, Explorations in Economic History, 38, 411-447

Allen, Robert C. (2013) Consumer price index for London, www.nuff.ox.ac.uk/People/sites/Allen/Shared\%20Documents/Forms/AllItems.aspx, accessed 15 April 2013

Beveridge, William, H. (1939) Prices and Wages in England from the Twelfth to the Nineteenth Century, London: Longmans Green

Broadberry, Stephen, Bruce M.S. Campbell, Alexander Klein, Mark Overton and Bas van Leeuwen (2011) British economic growth 1270-1870: An Output-based Approach, at www2.1se.ac.uk/economicHistory/pdf/Broadberry/BritishGDPLongrun16a.pdf, accessed 15 April 2013

Campbell, Bruce M.S. (2007) Three centuries of English cropyields, 1011-1491, http://www.cropyields.ac.uk [accessed 12/08/2013]

Campbell, Bruce M.S. and Cormac O'Grada (2011) Harvest shortfalls, grain prices and famines in pre-industrial England, Journal of Economic History, 71 (4), 859-886 
Casson, Mark, Nigar Hashimzade and Catherine Casson (2013) Long-run price dynamics: The measurement of substitutability between commodities, in Casson, M. and N. Hashimzade (eds.) Large Databases in Economic History, Abingdon: Routledge, 23-61

Challis, C.E. (1992) A New History of the Royal Mint, Cambridge: Cambridge University Press

Clark, Gregory (2004) The price history of English agriculture, 1209-1914, Research in Economic History, 22, 41-123

Farmer, David L. (1991) Prices and wages, 1350-1500, in Edward Miller (ed.), The Agrarian History of England and Wales, Vol. III, 1348-1500, Cambridge: Cambridge University Press, 431-525

Friedman, Milton (1956) Studies in the Quantity Theory of Money, Chicago: University of Chicago Press

Fisher, Franklin M. (1966) The Identification Problem in Econometrics, New York: McGraw-Hill

Fisher, Irving, assisted by Harry G. Brown (1911) The Purchasing Power of Money, New York: Macmillan

Hatcher, John and Mark Bailey (2001) Modelling the Middle Ages, Oxford: Oxford University Press

Hoskins, W.G. (1964) Harvest fluctuations and English economic history, 1480-1619, Agricultural History Review, 12 (1), 28-46

Kenny, David A. (1979) Correlation and Causality, New York: Wiley

Mayhew, N.J. (1995) Population, money supply and the velocity of circulation in England, 1300-1700, Economic History Review, 48, 238-257

Mayhew, Nicholas J. (2013a) Prices in England, 1170-1750, Past and Present, No. 219, May, 3-39

Mayhew, Nicholas J. (2013b) The Quantity Theory of Money in historical perspective, in Casson, M. and N.Hashimzade (eds.) Large Databases in Economic History, Abingdon: Routledge, 62-96

Nerlove, Marc (1958) The Dynamics of \Supply: estimation of Farmers' responses o price, Baltimore, MD: Johns Hopkins University Press

Phelps-Brown, E. Henry and Sheila V. Hopkins (1962) Seven centuries of the prices of consumables, compared with builders' wage-rates, in E.M. Carus-Wilson (ed.) Essays in Economic History, London: Edward Arnold, 179-196 
Postan, Michael M. (1973) Medieval Trade and Finance, Cambridge: Cambridge University Press

Thorold Rogers, James E. (1866-1902) A History of Agriculture and Prices in England, 1259-1793, 7 vols., Oxford: Oxford University Press

Wooldridge, Jeffrey M. (2014) Introductory Econometrics: A Modern Approach, Andover, Hants: Cengage Learning

Acknowledgement

We are grateful to Nigar Hashimzade, Janet Casson and the editors for helpful comments on a previous draft. 


\section{Appendix}

This appendix extends Mayhew's (2013b) model. Mayhew presents a single-equation model based upon a generalisation of the QT. His model explains the price level in terms of money supply, population and GDP per head. This appendix presents a three-equation model which simultaneously explains the price level, GDP per head and the money wage rate. The basic structure of the model is explained in the text. This appendix shows how the estimated equations are derived using the principles of partial adjustment and persistent shocks. The three equations are discussed in turn.

\section{Price equation}

The QT relates the long run price level to money supply and income. The actual price level is determined by a short-run partial adjustment mechanism. Actual price in any year adjusts by a fraction of the discrepancy between the current long run price and the price in the previous period. This is described as the weak version of the QT by Mayhew.

The QT is a multiplicative relationship which is most conveniently analysed in terms of logarithms. In the classic QT the velocity of circulation of money is constant, but experience suggests that it changes over time. Long term institutional changes may be captured by a deterministic time trend, whilst short term fluctuations may be attributed to a Keynesian effect in which the velocity of circulation increases with respect to income; with a given money supply, an increase in income may raise interest rates, causing households to economise on money balances, and as a result money circulates faster.

Let $P_{t}$ be the logarithm of the actual price level in period $t, P^{*}$ be the logarithm of the target price level, $Q_{t}$ the logarithm of the level of GDP, $M_{t}$ the logarithm of the level of money supply, and $V_{t}$ the logarithm of the velocity of circulation of money. The money supply has two components, silver and gold. The effective money supply is a weighted geometric average of the stocks of silver and gold. Thus $M_{t}$ is a weighted arithmetic average of the logarithm of the silver stock, $M_{1 t}$, and the logarithm of the gold stock, $M_{2 t}$. GDP may be expressed as the product of income per head and population; thus $Q_{t}$ is the sum of the logarithm of income per head, $Y_{t}$, and the logarithm of population, $N_{t}$. The velocity of circulation depends on a time trend and also varies directly with income. In addition, let $e_{t}$ be a random shock that influences the partial adjustment process in period $t$. The relationships may be summarised as follows:

$$
\begin{aligned}
& P_{t}=k\left(P_{t}-P_{t-1}\right)+P_{t-1}+e_{t}=k P_{t}^{*}+(1-k) P_{t-1}+e_{t} \\
& P_{t}^{*}=V_{t}+M_{t}-Q_{t} \\
& V_{t}=v_{0}+c_{1} t+c_{2} Y t \\
& M_{1 t}=d M_{1 t}+(1-d) M_{2 t} \\
& Q_{t}=Y_{t}+N_{t}
\end{aligned}
$$


In equation (1.1) $k$ is the partial adjustment coefficient $(0 \leq k \leq 1)$; in equation (1.3) $v_{0}$ is the logarithm of the autonomous component of the velocity of circulation, $c_{1}$ measures the impact of the time trend, and $c_{2}$ is the elasticity of the velocity of circulation with respect to income. In equation (1.4) $d$ is a measure of the relative impact on price of a nominal stock of silver relative to the impact of an equivalent nominal stock of gold.

Substituting (1.3) - (1.5) into (1.2) gives

$$
P^{*} t_{t}=v_{0}+c_{1} t-\left(1-c_{2}\right) Y_{t}-N_{t}+d M_{1 t}+(1-d) M_{2 t}
$$

Substituting (2) into (1.1) and re-arranging terms gives:

$$
P_{t}=k v_{0}+(1-k) P_{t-1}-k\left(1-c_{2}\right) Y_{t}-k N_{t}+k d M_{1 t}+k(1-d) M_{1 t}+k c_{1} t+e_{t}
$$

Suppose now that $e_{t}$ follows a first-order auto-regressive process:

$$
e_{t}=h_{1} e_{t-1}+u_{t}
$$

where $u_{t}$ represents a white-noise process. Lagging equation (3) by one period, multiplying through by $j$, subtracting the result from (3) and applying equation (4) gives

$$
\begin{aligned}
& P_{t}=\left[k\left(1-h_{1}\right) v_{0}+j_{1} k c_{1}\right]+h_{1} P_{t-1}-h_{1}(1-k) P_{t-2}+k\left(1-c_{2}\right) Y_{t}-h_{1} k\left(1-c_{2}\right) Y_{t-1}-k N_{t} \\
& +h_{1} k N_{t-1}+k d M_{1 t}-h_{1} k d M_{1 t-1}+k(1-d) M_{2 t}-h_{1} k(1-d) M_{2 t-1}+\left(1-h_{1}\right) k c_{1} t+e_{t}
\end{aligned}
$$

Equation (5) asserts that current price depends linearly on its own previous valued (lagged for one and two years, current and lagged GDP per head, current and lagged population, current and lagged silver stock, current and lagged gold stock, and a time trend. For purposes of statistical estimation it is useful to embed this equation within a more general specification.

- Extend the number of lags to three years for prices, GDP and money stock. This makes it possible to test whether a third lag has no significant impact on price, as suggested by the model.

- Include just a single population variable, corresponding to a one year lag. Population changes only very slowly and so current population is highly correlated with lagged population and, in addition population is highly correlated with a linear time trend. Including lagged population and a time trend creates problems of multicollinearity (high standard errors and computational problems).

- Include lagged wage rates, to allow for the possibility of 'cost push' inflation that is excluded from the simple QT model.

- Include crop yields, as explained in the text.

- Estimate the equations by ignoring the cross-coefficient restrictions implied by the theory. Imposing restrictions on coefficients prior to estimation considerably complicates the estimation process.

\section{Income equation}


The income equation is formulated as an aggregate supply equation in which the amount of output forthcoming in any period increases with the expected price. Price expectations are formed in the previous period, when output decisions are made. This conforms to the situation where a crop is planted in one year and taken to market in the next. If all prices and wages rose or fell by the same proportion from year to year then there would be little point in adjusting output, because any gain to a producer arising from a higher price the following year would be lost when they came to spend their income because of the higher cost of living. If money wages are stickier than prices, however, then a rise in price may increase real profit margins and make additional production worthwhile.

It is convenient to formulate the output equation in terms of income per head, $Y_{t}$. Let $P^{e}{ }_{t}$ be the expected price in period $t$ and assume that it is based on a weighted average of current and previous prices in the previous period, $P_{t-1}, P_{t-2}$. Some wage costs may be incurred in the year $t-1$ and some in year $t$. The wage rate $W_{t-1}$ is known at the time that the output decision is made, but the wage rate $W_{t}$ must be predicted, and predictions may be based on previous wages, such as $W_{t-2}$. Downward pressure on future money wages may be expected if low current output, $Y_{t-1}$, has created unemployment, or if high population, $N_{t-1}$, has stimulated the supply of labour. The expected profit margin is determined by the relation between expected prices and expected wages.

Output $Y_{t}$, therefore depends upon lagged prices, $P_{t-1}, P_{t-2}$, lagged wages, $W_{t-1}, W_{t-2}$, lagged income, $Y_{t-1}$ and lagged population, $N_{t-1}$. Let $e_{2 t}$ be a production shock that influences output once decisions have been made. The output equation may be written

$$
Y_{t}=a_{0}+a_{1} P_{t-1}+a_{2} P_{t-2}+a_{3} W_{t-1}+a_{4} W_{t-1}+a_{5} Y_{t-1}+a_{6} N_{t-1}+e_{2 t}
$$

Assuming an autoregressive process in $e_{2 t}$, with parameter $h_{2}$, equation (6) implies that

$$
\begin{gathered}
Y_{t}=a_{0}+a_{1} P_{t-1}+\left(a_{2}-h_{2} a_{1}\right) P_{t-2}-h_{2} a_{2} P_{t-3}+a_{3} W_{t-1}+\left(a_{4}-h_{2} a_{3}\right) W_{t-2-} \\
h_{2} a_{4} W_{t-3}+a_{5} Y_{t-1}-h_{2} a_{5} Y_{t-2}+a_{6} N_{t-1}-h_{2} a_{6} N_{t-2}+u_{2 t}
\end{gathered}
$$

where $u_{2 t}$ is a white-noise process.

A more general specification would allow for the influence of short term fluctuations in crop yields on aggregate output, and also the possibility of long-term changes due to technological progress, new resources, climate change, and so on. These can be introduced by expanding the random component to include a time trend and crop yield variables. This suggests that the explanatory variables for output should be lagged prices, lagged wages, lagged income and lagged population, together with crop yields and a time trend. For reasons of multicollinearity, only one lagged value of population should be used.

\section{Money wage rate equation}

A preliminary assessment of the data reveals that during the period of this study money wages changed only intermittently, and then jumped up or down by quite large amounts. None of the other variables included in this study exhibit similar behaviour. This suggests the 
presence of unobservable factors that influence money wages and that exhibit a high degree of persistence. This in turn argues strongly for including lagged values of the wage in the wage equation. The direction of changes in wages, when they occur, could reflect changes in prices in the period since the last major change. This is consistent with a 'catch up' theory of money wages in which wages adjust from time to time in order to stabilise the cost of living. This implies that lagged prices should also be included in the wage equation. Theory suggests that the long run real wage will depend on the level of employment and the size of population. Overall, therefore, theory suggests the exogenous variables in the wage equation should be the same as those in the income equation, even though the rationale for their inclusion is rather different. 
Table 1: Zero-order Pearson correlation coefficients between key variables

\begin{tabular}{|c|c|c|c|c|c|c|c|c|}
\hline & Log price & $\begin{array}{l}\text { Log } \\
\text { silver } \\
\text { stock }\end{array}$ & $\begin{array}{l}\text { Log gold } \\
\text { stock }\end{array}$ & $\begin{array}{l}\text { Log GDP } \\
\text { per head }\end{array}$ & $\begin{array}{l}\text { Log } \\
\text { population }\end{array}$ & Log wage & $\begin{array}{l}\text { Crop } \\
\text { yield } \\
\text { index }\end{array}$ & Time \\
\hline Log price & $\begin{array}{c}1.000 \\
246\end{array}$ & & & & & & & \\
\hline $\begin{array}{l}\text { Log silver } \\
\text { stock }\end{array}$ & $\begin{array}{c}0.380 \\
(0.000) \\
246\end{array}$ & $\begin{array}{l}1.000 \\
246 \\
\end{array}$ & & & & & & \\
\hline $\begin{array}{l}\text { Log gold } \\
\text { stock }\end{array}$ & $\begin{array}{c}-0.067 \\
(0.381) \\
176\end{array}$ & $\begin{array}{c}-0.042 \\
(0.572) \\
176\end{array}$ & $\begin{array}{c}1.000 \\
246\end{array}$ & & & & & \\
\hline $\begin{array}{l}\text { Log GDP } \\
\text { per head }\end{array}$ & $\begin{array}{c}-0.666 \\
(0.000) \\
246\end{array}$ & $\begin{array}{c}-0.704 \\
(0.000) \\
246\end{array}$ & $\begin{array}{c}0.492 \\
(0.000) \\
176\end{array}$ & $\begin{array}{c}1.000 \\
246\end{array}$ & & & & \\
\hline $\begin{array}{l}\text { Log } \\
\text { population }\end{array}$ & $\begin{array}{c}0.617 \\
(0.000) \\
246 \\
\end{array}$ & $\begin{array}{c}0.747 \\
(0.000) \\
246 \\
\end{array}$ & $\begin{array}{c}-0.566 \\
(0.000) \\
176 \\
\end{array}$ & $\begin{array}{c}-0.934 \\
(0.000) \\
246 \\
\end{array}$ & $\begin{array}{l}1.000 \\
246 \\
\end{array}$ & & & \\
\hline Log wage & $\begin{array}{c}0.270 \\
(0.000) \\
246\end{array}$ & $\begin{array}{c}-0.483 \\
(0.000) \\
246\end{array}$ & $\begin{array}{c}0.401 \\
(0.000) \\
176\end{array}$ & $\begin{array}{c}0.363 \\
(0.000) \\
246\end{array}$ & $\begin{array}{c}-0.384 \\
(0.000) \\
246\end{array}$ & $\begin{array}{c}1.000 \\
246\end{array}$ & & \\
\hline $\begin{array}{l}\text { Crop yield } \\
\text { index }\end{array}$ & $\begin{array}{c}-0.080 \\
(0.269) \\
195\end{array}$ & $\begin{array}{c}0.222 \\
(0.002) \\
195\end{array}$ & $\begin{array}{c}-0.007 \\
(0.938) \\
125\end{array}$ & $\begin{array}{c}-0.119 \\
(0.098) \\
195\end{array}$ & $\begin{array}{c}0.332 \\
(0.000) \\
195\end{array}$ & $\begin{array}{c}-0.040 \\
(0.576) \\
195\end{array}$ & $\begin{array}{c}1.000 \\
246\end{array}$ & \\
\hline Time & $\begin{array}{c}-0.196 \\
(0.000) \\
246\end{array}$ & $\begin{array}{c}-0.492 \\
(0.000) \\
246\end{array}$ & $\begin{array}{c}0.286 \\
(0.000) \\
176\end{array}$ & $\begin{array}{c}0.876 \\
(0.000) \\
246\end{array}$ & $\begin{array}{c}-0.843 \\
(0.000) \\
246\end{array}$ & $\begin{array}{c}0.075 \\
(0.000) \\
246\end{array}$ & $\begin{array}{c}-0.292 \\
(0.000) \\
195\end{array}$ & $\begin{array}{c}1.000 \\
246 \\
\end{array}$ \\
\hline
\end{tabular}

Note: There are occasional missing observations in the monetary series. The correlations between prices, silver stock, GDP per head, population and time were all estimated from a sub-sample of 246 observations. The correlations between these variable and gold stocks were estimated from a sub-sample of 176 observations commencing in 1344 . The correlations between these variables and crop yields were estimated from a sub-sample terminating in 1470. The correlation between gold stock and crop yield was estimated from a sub-sample of 125 observations 1344-1470. 
Table 2: Autocorrelations of key variables

\begin{tabular}{|l|l|l|l|l|l|l|}
\hline \multirow{2}{*}{ Variable } & \multicolumn{7}{|c|}{ Annual lag } \\
\cline { 2 - 7 } & 1 & 2 & 3 & 4 & 5 & 6 \\
\hline Log price & 0.910 & 0.811 & 0.763 & 0.756 & 0.769 & 0.770 \\
\hline Log silver stock & 0.978 & 0.970 & 0.959 & 0.945 & 0.931 & 0.915 \\
\hline Log gold stock & 0.907 & 0.808 & 0.710 & 0.624 & 0.541 & 0.459 \\
\hline Log GDP per head & 0.952 & 0.922 & 0.910 & 0.898 & 0.884 & 0.880 \\
\hline Log population & 0.994 & 0.985 & 0.975 & 0.965 & 0.954 & 0.944 \\
\hline Log wage & 0.969 & 0.941 & 0.911 & 0.875 & 0.835 & 0.795 \\
\hline Crop yield index & 0.301 & 0.133 & 0.208 & 0.222 & 0.177 & 0.176 \\
\hline
\end{tabular}

Note: All series except crop yields exhibit high levels of autocorrelation. Population exhibits the highest degree of autocorrelation. If a shock to a population is a birth, then persistence reflects average life expectancy. This suggests that the impacts of shocks on money, prices, wages and incomes persist for less than the average life of an individual. 
Table 3: Augmented Dickey-Fuller tests for key variables

\begin{tabular}{|l|l|l|l|}
\hline \multirow{2}{*}{} & \multicolumn{2}{|l|}{ Test for levels } & $\begin{array}{l}\text { Test for first } \\
\text { differences }\end{array}$ \\
\cline { 2 - 4 } & $\begin{array}{l}\text { ADF statistic before } \\
\text { removal of linear } \\
\text { trend }\end{array}$ & $\begin{array}{l}\text { ADF statistic after } \\
\text { removal of linear } \\
\text { trend }\end{array}$ & $\begin{array}{l}\text { ADF statistic after } \\
\text { removal of linear } \\
\text { trend }\end{array}$ \\
\hline Log price & -1.742 & $-4.451^{* * *}$ & -12.609 \\
& $(0.409)$ & $(0.002)$ & $(0.000)$ \\
\hline Log silver stock & -0.920 & -0.525 & -6.190 \\
& $(0.781)$ & $(0.982)$ & $(0.000)$ \\
\hline Log gold stock & -3.173 & $-3.172^{*}$ & -4.687 \\
& $(0.023)$ & $(0.094)$ & $(0.001)$ \\
\hline Log GDP per head & -1.478 & -2.643 & -12.895 \\
& $(0.543)$ & $(0.262)$ & $(0.000)$ \\
\hline Log population & -1.425 & -1.234 & -4.835 \\
& $(0.570)$ & $(0.900)$ & $(0.001)$ \\
\hline Log wage & -1.991 & -1.865 & -16.813 \\
& $(0.291)$ & $(0.670)$ & $-10.000)$ \\
\hline Crop yield index & $-10.208^{* * *}$ & $-11.061^{* * *}$ & $(0.000)$ \\
\hline & $(0.000)$ & $(0.000)$ & \\
\hline
\end{tabular}

Note: * indicates 10 per cent significance, $* * 5$ per cent significance and $* * * 1$ per cent significance. 
Table 4: Summary of impacts in the SEM

\begin{tabular}{|c|c|c|c|c|}
\hline Ref & Impact & $\begin{array}{l}\text { Expected } \\
\text { sign }\end{array}$ & $\begin{array}{l}\text { Actual sign } \\
\text { (if } \\
\text { significant) }\end{array}$ & Comment \\
\hline 1 & Price persistence & + & + & $\begin{array}{l}\text { AGREEMENT About } 30 \text { per cent of } \\
\text { a price shock persists to the } \\
\text { following year }\end{array}$ \\
\hline 2 & Income persistence & + & + & $\begin{array}{l}\text { AGREEMENT About } 70 \text { per cent of } \\
\text { an income shock persists to the } \\
\text { following year }\end{array}$ \\
\hline 3 & Wage persistence & + & + & $\begin{array}{l}\text { AGREEMENT About } 90 \text { per cent of } \\
\text { a wage shock persists to the } \\
\text { following year }\end{array}$ \\
\hline $4 a$ & $\begin{array}{l}\text { QT elasticity of price } \\
\text { with respect to silver }\end{array}$ & + & + & $\begin{array}{l}\text { AGREEMENT Price adjusts to the } \\
\text { lagged silver stock; if silver stock is } \\
\text { above trend then on average price is } \\
\text { above trend too }\end{array}$ \\
\hline $4 \mathrm{~b}$ & $\begin{array}{l}\text { QT elasticity of price } \\
\text { with respect to gold }\end{array}$ & + & & $\begin{array}{l}\text { DISAGREEMENT Price is not } \\
\text { significantly influenced by the gold } \\
\text { stock }\end{array}$ \\
\hline 5 & $\begin{array}{l}\text { QT elasticity of price } \\
\text { with respect to } \\
\text { current income }\end{array}$ & - & & $\begin{array}{l}\text { DISAGREEMENT Price is not } \\
\text { significantly influenced by current } \\
\text { GDP per head }\end{array}$ \\
\hline 6 & $\begin{array}{l}\text { Elasticity of output } \\
\text { response with } \\
\text { respect to price }\end{array}$ & + & + & $\begin{array}{l}\text { AGREEMENT An increase in price } \\
\text { leads to a significant increase in } \\
\text { output the following year }\end{array}$ \\
\hline 7 & $\begin{array}{l}\text { Elasticity of output } \\
\text { response with } \\
\text { respect to wage }\end{array}$ & - & & $\begin{array}{l}\text { DISAGREEMENT Output is } \\
\text { independent of wage rates the } \\
\text { previous year }\end{array}$ \\
\hline 8 & $\begin{array}{l}\text { Direct wage- } \\
\text { elasticity of price }\end{array}$ & + & + & $\begin{array}{l}\text { AGREEMENT Increases in wages } \\
\text { are passed on in higher prices. The } \\
\text { wage-elasticity of price is very high } \\
\text { (greater than one) }\end{array}$ \\
\hline 9 & $\begin{array}{l}\text { Cost of living } \\
\text { adjustment: price- } \\
\text { elasticity of wage } \\
\end{array}$ & + & & $\begin{array}{l}\text { DISAGREEMENT There is no } \\
\text { significant cost of living adjustment }\end{array}$ \\
\hline 10 & $\begin{array}{l}\text { QT elasticity of price } \\
\text { with respect to } \\
\text { previous income }\end{array}$ & - & & $\begin{array}{l}\text { DISAGREEMENT Price is not } \\
\text { significantly influenced by lagged } \\
\text { GDP per head }\end{array}$ \\
\hline 11 & $\begin{array}{l}\text { Elasticity of wage } \\
\text { with respect to } \\
\text { previous income }\end{array}$ & + & & $\begin{array}{l}\text { DISAGREEMENT Wage rates are } \\
\text { not significantly influenced by } \\
\text { lagged GDP per head }\end{array}$ \\
\hline $12 \mathrm{a}$ & $\begin{array}{l}\text { Population-elasticity } \\
\text { of price }\end{array}$ & & & $\begin{array}{l}\text { Population significantly increases } \\
\text { price }\end{array}$ \\
\hline $12 b$ & Time trend in price & & - & $\begin{array}{l}\text { Prices decline significantly by about } \\
20 \text { per cent per century }\end{array}$ \\
\hline $13 \mathrm{a}$ & $\begin{array}{l}\text { Population-elasticity } \\
\text { of income }\end{array}$ & & & $\begin{array}{l}\text { High population significantly } \\
\text { reduces income per head }\end{array}$ \\
\hline $13 \mathrm{~b}$ & Time trend in & & + & GDP per head increases significantly \\
\hline
\end{tabular}




\begin{tabular}{|l|l|l|l|l|}
\hline & income & & & $\begin{array}{l}\text { but slowly by about 2 per cent per } \\
\text { century }\end{array}$ \\
\hline $14 \mathrm{a}$ & $\begin{array}{l}\text { Population-elasticity } \\
\text { of wage rate }\end{array}$ & - & - & $\begin{array}{l}\text { AGREEMENT High population } \\
\text { reduces the wage rate }\end{array}$ \\
\hline $14 \mathrm{~b}$ & Time trend in wage & & $\begin{array}{l}\text { Negative but small and insignificant } \\
\text { trend }\end{array}$ \\
\hline 15 & $\begin{array}{l}\text { Impact of crop yield } \\
\text { on log price }\end{array}$ & - & - & $\begin{array}{l}\text { AGREEMENT High crop yields } \\
\text { reduce price }\end{array}$ \\
\hline 16 & $\begin{array}{l}\text { Impact of crop yield } \\
\text { on log income }\end{array}$ & + & $\begin{array}{l}\text { AGREEMENT High crop yields } \\
\text { increase GDP per head }\end{array}$ \\
\hline 17 & $\begin{array}{l}\text { Impact of crop yield } \\
\text { on log wage }\end{array}$ & & $\begin{array}{l}\text { High crop yield do not affect wage } \\
\text { rates }\end{array}$ \\
\hline
\end{tabular}


Table 5: Determinants of logarithm of price index, 1263-1520

\begin{tabular}{|c|c|c|c|c|c|c|c|}
\hline \multirow[b]{2}{*}{ Explanatory variable } & \multicolumn{7}{|c|}{ Regression number } \\
\hline & 1 & 2 & 3 & 4 & 5 & 6 & 7 \\
\hline Constant & $\begin{array}{l}-0.225^{* * * *} \\
(0.000)\end{array}$ & $\begin{array}{l}-0.050^{* * * *} \\
(0.006)\end{array}$ & $\begin{array}{l}-0.049^{* * *} \\
(0.002)\end{array}$ & $\begin{array}{l}-0.404^{*} \\
(0.076)\end{array}$ & $\begin{array}{c}0.586^{*} \\
(0.086)\end{array}$ & $\begin{array}{l}-0.563 \\
(0.179)\end{array}$ & $\begin{array}{l}-1.486^{* *} \\
(0.001)\end{array}$ \\
\hline Time & $\begin{array}{l}-0.217 \text { *** } \\
(0.000)\end{array}$ & $\begin{array}{l}-0.052^{* * * *} \\
(0.000)\end{array}$ & $\begin{array}{l}-0.053 * * * \\
(0.000)\end{array}$ & $\begin{array}{l}-0.070 * * * \\
(0.000)\end{array}$ & $\begin{array}{l}-0.011 \\
(0.689)\end{array}$ & $\begin{array}{l}-0.040^{*} \\
(0.089)\end{array}$ & $\begin{array}{l}-0.150 * * * \\
(0.000)\end{array}$ \\
\hline Price lagged 1 year & & $\begin{array}{l}0.767 * * * \\
(0.000)\end{array}$ & $\begin{array}{l}0.933 * * * \\
(0.000)\end{array}$ & $\begin{array}{l}0.924 * * * \\
(0.000)\end{array}$ & $\begin{array}{l}0.916 * * * \\
(0.000)\end{array}$ & $\begin{array}{l}0.782 * * * \\
(0.000)\end{array}$ & $\begin{array}{l}0.601 * * * \\
(0.000)\end{array}$ \\
\hline Price lagged 2 years & & & $\begin{array}{l}-0.335^{* * *} \\
(0.000)\end{array}$ & $\begin{array}{l}-0.341 * * * \\
(0.000)\end{array}$ & $\begin{array}{l}-0.294 * * * \\
(0.001)\end{array}$ & $\begin{array}{l}-0.290 * * * \\
(0.000)\end{array}$ & $\begin{array}{l}-0.199 * * * \\
(0.008)\end{array}$ \\
\hline Price lagged 3 years & & & $\begin{array}{l}0.168^{* * * *} \\
(0.003)\end{array}$ & $\begin{array}{l}0.166^{* * *} \\
(0.004)\end{array}$ & $\begin{array}{l}0.166^{* * *} \\
(0.001)\end{array}$ & $\begin{array}{c}0.065 \\
(0.273)\end{array}$ & $\begin{array}{c}0.012 \\
(0.839)\end{array}$ \\
\hline Silver stock & & & & $\begin{array}{c}0.011 \\
(0.311)\end{array}$ & $\begin{array}{l}-0.008 \\
(0.549)\end{array}$ & $\begin{array}{c}0.015^{*} \\
(0.0667)\end{array}$ & $\begin{array}{l}0.051^{* *} \\
(0.001)\end{array}$ \\
\hline Gold stock & & & & $\begin{array}{r}0.017 \\
(0.207)\end{array}$ & $\begin{array}{c}0.026^{*} \\
(0.058)\end{array}$ & $\begin{array}{c}0.015 \\
(0.296)\end{array}$ & $\begin{array}{l}-0.011 \\
(0.505)\end{array}$ \\
\hline Dummy 1344 & & & & $\begin{array}{c}0.202 \\
(0.268)\end{array}$ & $\begin{array}{c}0.306^{*} \\
(0.074)\end{array}$ & $\begin{array}{c}0.094 \\
(0.616)\end{array}$ & $\begin{array}{l}-0.236 \\
(0.259)\end{array}$ \\
\hline GDP per head & & & & & $\begin{array}{l}-0.928 * * * \\
(0.000)\end{array}$ & $\begin{array}{l}-1.006^{* * * *} \\
(0.000)\end{array}$ & $\begin{array}{l}-0.094 \\
(0.719)\end{array}$ \\
\hline Population & & & & & $\begin{array}{l}-0.184 \\
(0.158)\end{array}$ & $\begin{array}{c}0.071 \\
(0.634)\end{array}$ & $\begin{array}{c}0.292 \\
(0.125)\end{array}$ \\
\hline Wage lagged 1 year & & & & & & $\begin{array}{l}0.909 * * * \\
(0.000)\end{array}$ & $\begin{array}{l}1.324 * * * \\
(0.000)\end{array}$ \\
\hline Crop yield & & & & & & & $\begin{array}{l}-0.233^{* * *} \\
(0.000)\end{array}$ \\
\hline$R^{2}$ & 0.598 & 0.842 & 0.852 & 0.854 & 0.865 & 0.880 & 0.856 \\
\hline Adjusted $R^{2}$ & 0.597 & 0.841 & 0.850 & 0.849 & 0.860 & 0.874 & 0.847 \\
\hline$F$ & $\begin{array}{l}379.6 * * * \\
(0.000)\end{array}$ & $\begin{array}{l}676.7 * * * \\
(0.000)\end{array}$ & $\begin{array}{l}359.3 * * * \\
(0.000)\end{array}$ & $\begin{array}{l}\text { 273.6*** } \\
(0.000)\end{array}$ & $\begin{array}{l}168.5 * * * \\
(0.000)\end{array}$ & $\begin{array}{l}171.6 * * * \\
(0.000)\end{array}$ & $\begin{array}{l}98.5^{* * * *} \\
(0.000)\end{array}$ \\
\hline Normality & $\begin{array}{l}87.6^{* * * *} \\
(0.000)\end{array}$ & $\begin{array}{l}75.7 * * * \\
(0.000)\end{array}$ & $\begin{array}{l}68.0 * * * \\
(0.000)\end{array}$ & $\begin{array}{l}66.4 * * * \\
(0.000)\end{array}$ & $\begin{array}{l}41.1 * * * \\
(0.000)\end{array}$ & $\begin{array}{l}18.2 * * * \\
(0.000)\end{array}$ & $\begin{array}{l}19.1 * * \\
(0.000)\end{array}$ \\
\hline Serial correlation & $\begin{array}{l}186.4 * * * \\
(0.000)\end{array}$ & $\begin{array}{l}8.1 * * * \\
(0.000) \\
\end{array}$ & $\begin{array}{l}4.9 * * * \\
(0.008)\end{array}$ & $\begin{array}{l}4.7 \\
(0.010)\end{array}$ & $\begin{array}{r}5.8 * * * \\
(0.003) \\
\end{array}$ & $\begin{array}{l}2.7 * \\
(0.071)\end{array}$ & $\begin{array}{l}0.8 \\
(0.465) \\
\end{array}$ \\
\hline Heteroskedasticity & $\begin{array}{l}11.5 * * * \\
(0.001)\end{array}$ & $\begin{array}{l}9.9 * * * * \\
(0.000)\end{array}$ & $\begin{array}{l}4.4 * * * \\
(0.002)\end{array}$ & $\begin{array}{l}3.0 * * * \\
(0.005)\end{array}$ & $\begin{array}{l}3.6 \\
(0.000)\end{array}$ & $\begin{array}{l}3.3^{* * * *} \\
(0.000)\end{array}$ & $\begin{array}{l}1.4 \\
(0.158)\end{array}$ \\
\hline No. observations & 257 & 256 & 254 & 249 & 246 & 246 & 195 \\
\hline
\end{tabular}

Note: * indicates 10 per cent significance, $* * 5$ per cent significance and $* * * 1$ per cent significance. Prices, GDP, money stock, wage and population are all measured in logarithms. White robust standard errors. Normality of the residuals is tested using a Jarque-Bera test. Serial correlation is tested using a Breusch-Godfrey LM test based on an $F$-statistic with two lags. Heteroskadasticity is tested using a Breusch-Pagan-Godfrey test based on an $F$-statistic. These estimates are based on data as collected by the authors from the originators on or shortly before 1 October 2013. Some of the data series may have been revised since then. 
Table 6: Estimation of full system, 1273-1470

\begin{tabular}{|c|c|c|c|c|c|}
\hline $\begin{array}{l}\text { Explanatory } \\
\text { variables }\end{array}$ & Price & $\begin{array}{l}\text { Explanatory } \\
\text { variables }\end{array}$ & GDP per head & $\begin{array}{l}\text { Explanatory } \\
\text { variables }\end{array}$ & Money wage \\
\hline Constant & $\begin{array}{l}-2.092 * * * \\
(0.002)\end{array}$ & Constant & $\begin{array}{c}0.304 \\
(0.000)\end{array}$ & Constant & $\begin{array}{c}0.148 \\
(0.048) \\
\end{array}$ \\
\hline Time & $\begin{array}{l}-0.215^{* * * *} \\
(0.000)\end{array}$ & Time & $\begin{array}{c}0.020 \\
(0.002)\end{array}$ & Time & $\begin{array}{l}-0.008 \\
(0.213)\end{array}$ \\
\hline Price lag 1 & $\begin{array}{l}0.286^{* * *} \\
(0.005)\end{array}$ & Price lag 1 & $\begin{array}{c}0.034 \\
(0.028) \\
\end{array}$ & Price lag 1 & $\begin{array}{c}0.028 \\
(0.104) \\
\end{array}$ \\
\hline Price change lag 1 & $\begin{array}{l}0.298 * * * \\
(0.004)\end{array}$ & Price change lag 1 & $\begin{array}{l}-0.012 \\
(0.466) \\
\end{array}$ & Price change lag 1 & $\begin{array}{l}-0.006 \\
(0.648)\end{array}$ \\
\hline Price change lag 2 & $\begin{array}{c}0.117 \\
(0.116) \\
\end{array}$ & Price change lag 2 & $\begin{array}{l}-0.016 \\
(0.278) \\
\end{array}$ & Price change lag 2 & $\begin{array}{l}-0.000 \\
(0.980)\end{array}$ \\
\hline Silver stock lag 1 & $\begin{array}{l}0.071 * * * \\
(0.000)\end{array}$ & & & & \\
\hline $\begin{array}{l}\text { Silver stock } \\
\text { change }\end{array}$ & $\begin{array}{l}-0.025 \\
(0.911)\end{array}$ & & & & \\
\hline $\begin{array}{l}\text { Silver stock } \\
\text { change lag } 1\end{array}$ & $\begin{array}{l}-0.047 \\
(0.838) \\
\end{array}$ & & & & \\
\hline $\begin{array}{l}\text { Silver stock } \\
\text { change lag } 2\end{array}$ & $\begin{array}{c}0.028 \\
(0.866) \\
\end{array}$ & & & & \\
\hline Gold stock lag 1 & $\begin{array}{l}-0.025 \\
(0.239)\end{array}$ & & & & \\
\hline Gold stock change & $\begin{array}{l}-0.033 \\
(0.199) \\
\end{array}$ & & & & \\
\hline $\begin{array}{l}\text { Gold stock change } \\
\text { lag } 1\end{array}$ & $\begin{array}{l}-0.009^{*} \\
(0.060)\end{array}$ & & & & \\
\hline $\begin{array}{l}\text { Gold stock change } \\
\text { lag } 2\end{array}$ & $\begin{array}{c}0.004 \\
(0.318) \\
\end{array}$ & & & & \\
\hline $\begin{array}{l}\text { GDP per head lag } \\
1\end{array}$ & $\begin{array}{c}0.318 \\
(0.445)\end{array}$ & $\begin{array}{l}\text { GDP per head lag } \\
1\end{array}$ & $\begin{array}{c}0.723 \\
(0.000)\end{array}$ & $\begin{array}{l}\text { GDP per head lag } \\
1\end{array}$ & $\begin{array}{l}-0.026 \\
(0.636)\end{array}$ \\
\hline $\begin{array}{l}\text { GDP per head } \\
\text { change }\end{array}$ & $\begin{array}{l}-0.227 \\
(0.578)\end{array}$ & & & & \\
\hline $\begin{array}{l}\text { GDP per head } \\
\text { change lag } 1\end{array}$ & $\begin{array}{l}-0.101 \\
(0.763) \\
\end{array}$ & $\begin{array}{l}\text { GDP per head } \\
\text { change lag } 1\end{array}$ & $\begin{array}{l}-0.012 \\
(0.865) \\
\end{array}$ & $\begin{array}{l}\text { GDP per head } \\
\text { change lag } 1\end{array}$ & $\begin{array}{l}-0.002 \\
(0.976)\end{array}$ \\
\hline $\begin{array}{l}\text { GDP per head } \\
\text { change lag } 2\end{array}$ & $\begin{array}{l}-0.201 \\
(0.535)\end{array}$ & $\begin{array}{l}\text { GDP per head } \\
\text { change lag } 2\end{array}$ & $\begin{array}{l}-0.125 \\
(0.084)\end{array}$ & $\begin{array}{l}\text { GDP per head } \\
\text { change lag } 2\end{array}$ & $\begin{array}{c}0.043 \\
(0.592)\end{array}$ \\
\hline Population lag 1 & $\begin{array}{c}0.405 \\
(0.078) \\
\end{array}$ & Population lag 1 & $\begin{array}{l}-0.109 \\
(0.001)\end{array}$ & Population lag 1 & $\begin{array}{l}-0.074 \\
(0.034)\end{array}$ \\
\hline Wage lag 1 & $\begin{array}{l}1.578 \\
(0.000) \\
\end{array}$ & Wage lag 1 & $\begin{array}{l}-0.037 \\
(0.365) \\
\end{array}$ & Wage lag 1 & $\begin{array}{c}0.915 \\
(0.000) \\
\end{array}$ \\
\hline $\begin{array}{l}\text { Wage change lag } \\
1\end{array}$ & $\begin{array}{l}-0.892 \\
(0.007)\end{array}$ & $\begin{array}{l}\text { Wage change lag } \\
1\end{array}$ & $\begin{array}{l}-0.010 \\
(0.908) \\
\end{array}$ & $\begin{array}{l}\text { Wage change lag } \\
1\end{array}$ & $\begin{array}{l}-0.107 \\
(0.136)\end{array}$ \\
\hline $\begin{array}{l}\text { Wage change lag } \\
2\end{array}$ & $\begin{array}{l}-0.681 \\
(0.045)\end{array}$ & $\begin{array}{l}\text { Wage change lag } \\
2\end{array}$ & $\begin{array}{l}-0.018 \\
(0.772)\end{array}$ & $\begin{array}{l}\text { Wage change lag } \\
2\end{array}$ & $\begin{array}{l}-0.021 \\
(0.681)\end{array}$ \\
\hline Crop yield & $\begin{array}{l}-0.237 \\
(0.000)\end{array}$ & Crop yield & $\begin{array}{c}0.074 \\
(0.000)\end{array}$ & Crop yield & $\begin{array}{l}-0.001 \\
(0.788)\end{array}$ \\
\hline Crop yield lag 1 & $\begin{array}{l}-0.018 \\
(0.655) \\
\end{array}$ & Crop yield lag 1 & $\begin{array}{l}-0.055 \\
(0.000) \\
\end{array}$ & Crop yield lag 1 & $\begin{array}{l}-0.003 \\
(0.699) \\
\end{array}$ \\
\hline Crop yield lag 2 & $\begin{array}{l}-0.006 \\
(0.868)\end{array}$ & Crop yield lag 2 & $\begin{array}{l}-0.000 \\
(0.986) \\
\end{array}$ & Crop yield lag 2 & $\begin{array}{l}-0.004 \\
(0.475)\end{array}$ \\
\hline Crop yield lag 3 & $\begin{array}{l}-0.033 \\
(0.347)\end{array}$ & Crop yield lag 3 & $\begin{array}{l}-0.007 \\
(0.425)\end{array}$ & Crop yield lag 3 & $\begin{array}{c}0.007 \\
(0.362)\end{array}$ \\
\hline Dummy 1344 & $\begin{array}{l}-0.439 \\
(0.115) \\
\end{array}$ & & & & \\
\hline$R^{2}$ & 0.870 & $R^{2}$ & 0.973 & $R^{2}$ & 0.940 \\
\hline Adjusted $R^{2}$ & 0.849 & Adjusted $R^{2}$ & 0.971 & Adjusted $R^{2}$ & 0.935 \\
\hline
\end{tabular}




\begin{tabular}{|l|l|l|l|l|l|}
\hline$F$ & $\begin{array}{l}42.0 * * * \\
(0.000)\end{array}$ & $F$ & $\begin{array}{l}424.6^{* * *} \\
(0.000)\end{array}$ & $F$ & $\begin{array}{l}186.0 * * * \\
(0.000)\end{array}$ \\
\hline Normality & $\begin{array}{l}28.7 * * * \\
(0.000)\end{array}$ & Normality & $\begin{array}{l}27.7 * * * \\
(0.000)\end{array}$ & Normality & $\begin{array}{l}2451.4 * * * \\
(0.000)\end{array}$ \\
\hline Serial correlation & $\begin{array}{l}0.9 \\
(0.409)\end{array}$ & Serial correlation & $\begin{array}{l}5.0 * * * \\
(0.008)\end{array}$ & Serial correlation & $\begin{array}{c}5.0 * * * \\
(0.008)\end{array}$ \\
\hline Heteroskedasticity & 0.9 & Heteroskedasticity & 1.0 & Heteroskedasticity & 0.7 \\
& $(0.592)$ & & & \\
$(0.428)$ & & & No. observations & 194 \\
\hline No. observations & 183 & No. observations & 194 & & \\
\hline
\end{tabular}


Figure 1

\section{Causal structure of the model}

Exogenous or

Endogenous variables

pre-determined variables

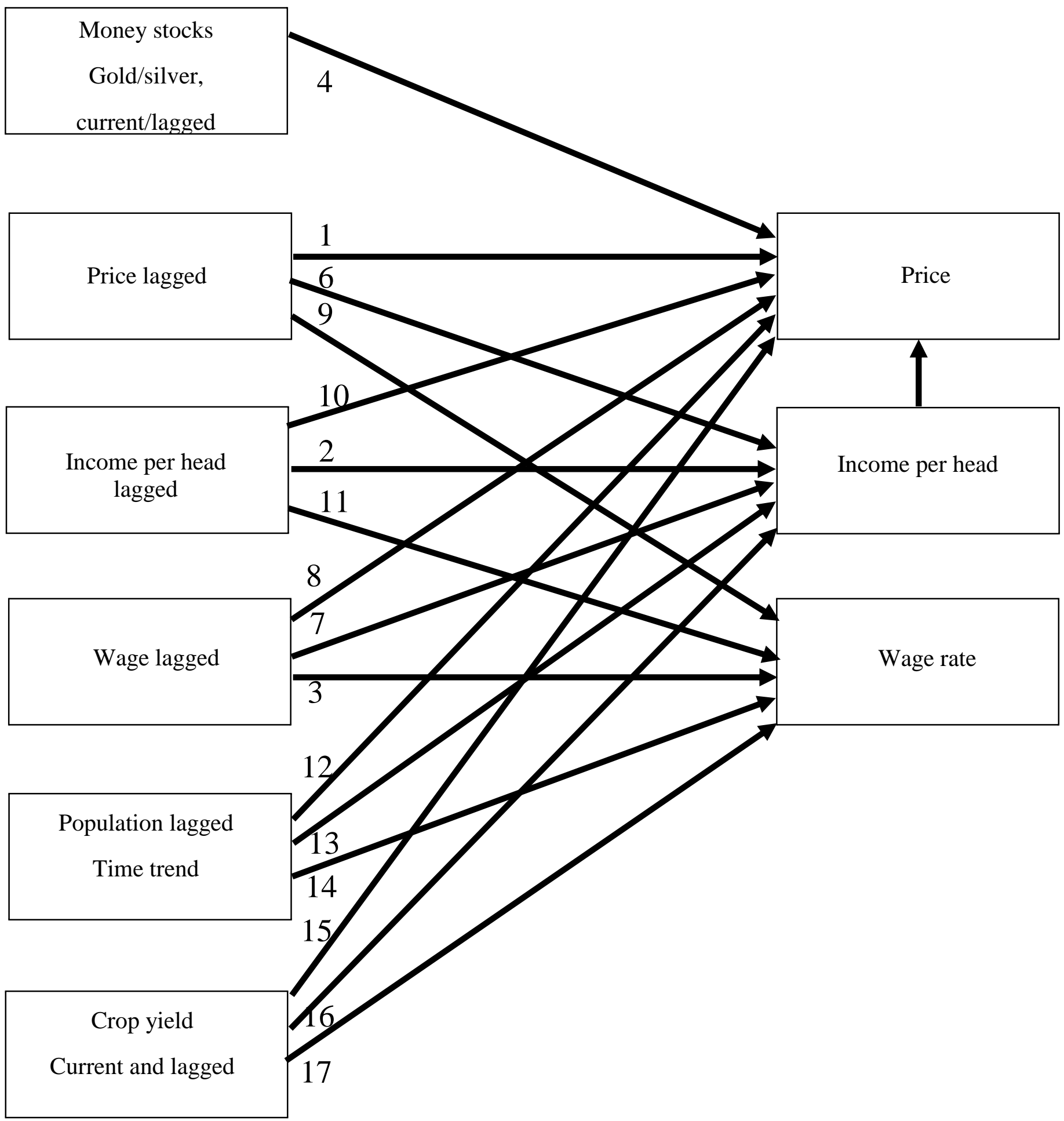


Figure 2: Actual, fitted and residual graphs for price regression, 1263-1520

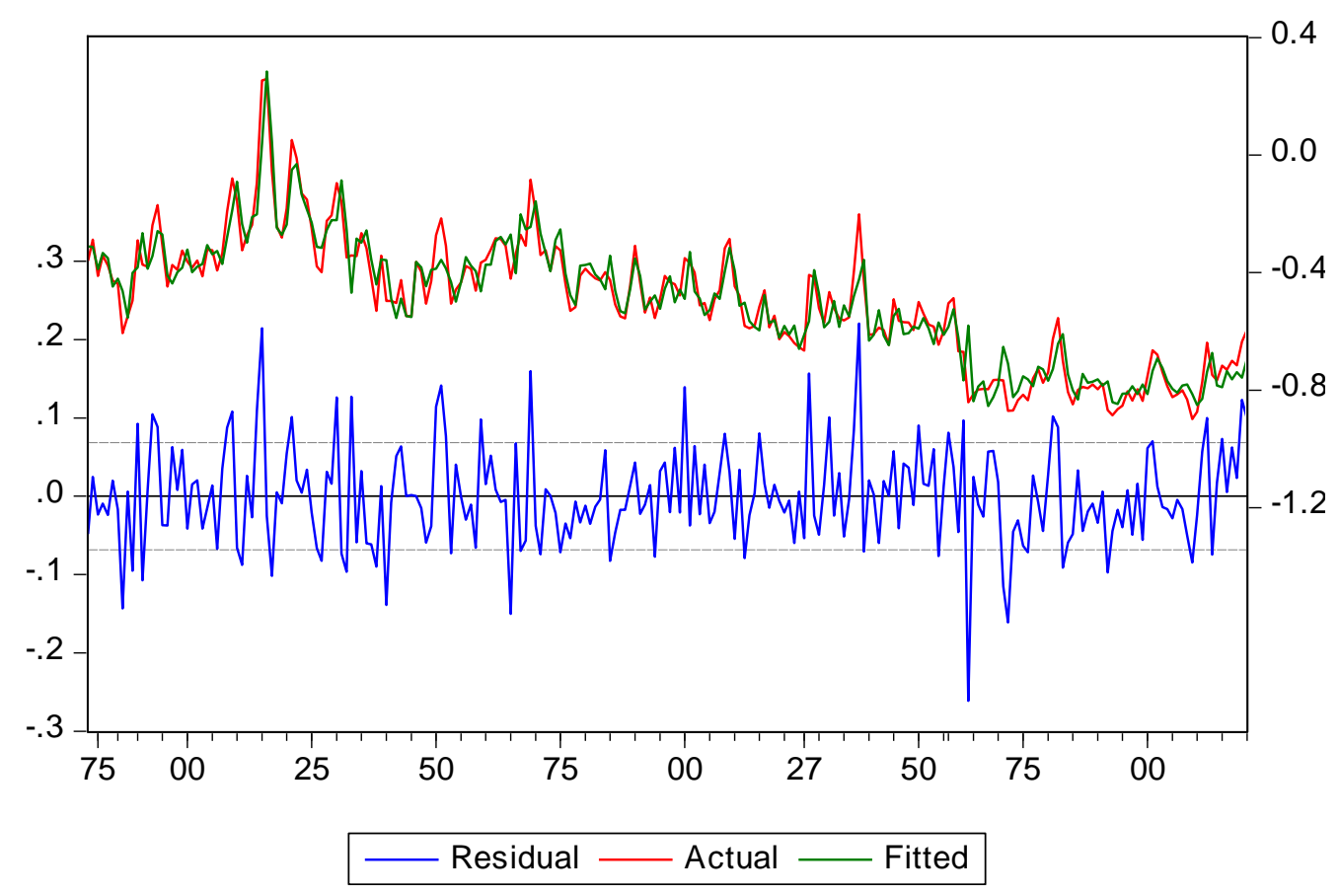


Figure 3: Actual, fitted and residual graphs for income per head equation, 1263-1520

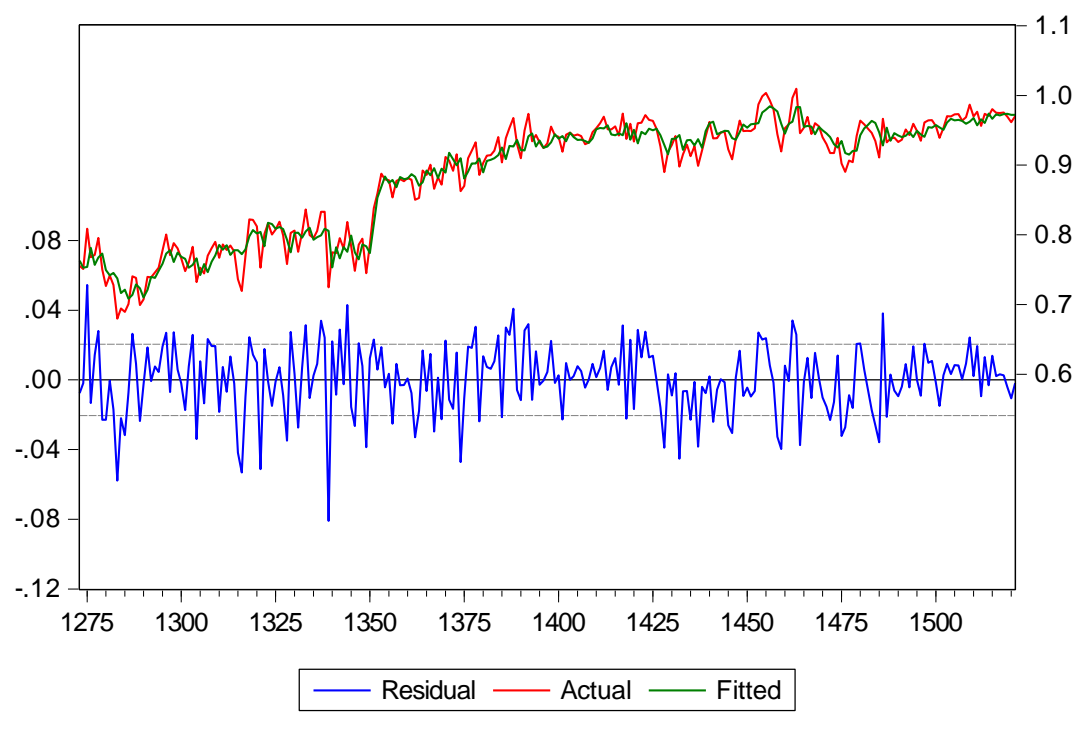


Figure 4: Actual, fitted and residual graphs for wage regression, 1263-1520

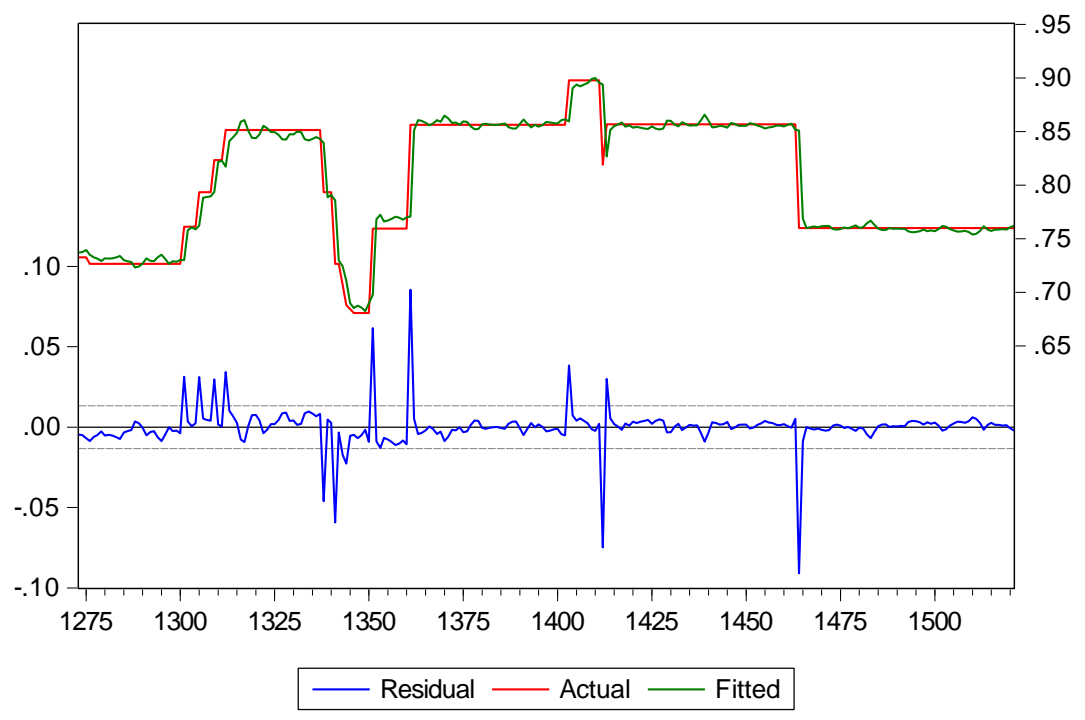

